\title{
Soil-site suitability evaluation for chickpea in micro-watershed of Wardha district, Maharashtra
}

\section{NILIMA S. SADANSHIV, PRAJAKTA M. METKARI AND YOGITAD. GORE}

Received : 15.09.2017; Revised : 17.11.2017; Accepted : 26.11 .2017

\section{MEMBERS OF RESEARCH FORUM:}

Corresponding author : NILIMA S. SADANSHIV, Department of Soil Science and Agricultural Chemistry, Dr. Panjabrao Deshmukh Krishi Vidyapeeth, AKOLA (M.S) INDIA

Co-authors :

PRAJAKTA M. METKARI AND YOGITA D. GORE, Department of Soil Science and Agricultural Chemistry, Dr. Panjabrao Deshmukh Krishi Vidyapeeth, AKOLA (M.S) INDIA

\section{Summary}

In the present study, soil-site suitability evaluation was made for the Nagalvadi microwatershed of Wardha district for chickpea (Cicer arietinum L.). Five soil series representing major land forms of Nagalvadi micro-watershed were evaluated for their suitability to chickpea cultivation using limitation method regarding number and intensity of limitations. The study suggests that chickpea is moderately suitable in soils of NG-2 and NG-5 but soils of NG-1, NG3 and NG-4 are not suitable for chickpea cultivation. Soil depth, wetness (drainage), texture, coarse fragments, soil $\mathrm{pH}$ and organic carbon are the major limitations for crop growth in the most of soils of Nagalvadi micro-watershed. The suitability classes can be improved if the correctable limitations (soil fertility characteristics) are altered through application of farm yard manure, green manuring and inclusion of legumes rotation.

Key words : Evaluation, Micro-watershed, Chickpea

How to cite this article : Sadanshiv, Nilima S., Metkari, Prajakta M. and Gore, Yogita D. (2017). Soilsite suitability evaluation for chickpea in micro-watershed of Wardha district, Maharashtra. Asian J. Soil Sci., 12 (2) : 323-327 : DOI : 10.15740/HAS/AJSS/12.2/323-327. 